\title{
The Impact of Social Transfers on Poverty Reduction in EU Countries
}

\author{
Rasa Miežienè \\ Sandra Krutulienè \\ Lithuanian Social Research Centre, \\ Labour Market Research Institute \\ Goštauto str. 9, \\ Vilnius 01108, Lithuania \\ E-mail: rasa.zabarauskaite@dsti.It \\ E-mail: sandra.krutuliene@dsti.It
}

\begin{abstract}
Available studies indicate a strong negative correlation between poverty and social expenditures in EU countries. It means that the country's at-risk-of-poverty rate tends to erode with increasing social expenditure. However, the studies have demonstrated that the impact of government spending on poverty may vary according to the sector of spending, how well it is targeted, and the way in which it is financed. Some countries manage to achieve a rather significant poverty rate reduction even with relatively low, in the context of other Member States, social expenditure (percentage of GDP). This suggests that in order to reduce poverty rates, it is important to consider not only the amount allocated to social spending, but also the areas the social transfers are channelled to. The article aims to analyse how the composition and the extent of social spending/transfers may affect poverty reduction in EU countries. The analysis showed that social protection transfers reduce the percentage of people atrisk-of-poverty in all countries, however, to a very different extent. Regression analysis demonstrated that social exclusion and family/ children expenditure was found to be the most important predictor for a relative antipoverty effect of social transfers: even a small percentage increase in such expenditure allows quite a significant increase in the relative antipoverty effect of social transfers.
\end{abstract}

Keywords: EU, poverty reduction, social protection expenditure, social transfers 


\section{Introduction}

Social spending is one of the most important instruments to fight against poverty in most countries. Eurostat estimates that in 2017 social transfers resulted in a reduction of almost one third (32.4\%) in the number of people classified as poor within the EU (pensions are not considered social transfers in these calculations). The extent to which social transfers reduce the number of people at risk of poverty varies across EU Member States. In 2017, there were three Member States where the number of people at risk of poverty was more than halved as a result of social transfers: Finland (a 56.9\% reduction), Ireland $(52.6 \%)$ and Denmark (51\%). In nine Member States the reduction was below $25 \%$, and of these the smallest reductions were in Greece (15.8\%) and Romania (16.6\%) (Eurostat, 2018). The question that arises is why some countries are more effective in alleviating poverty than others.

Many quantitative studies have showed that there is a strong negative correlation between poverty and social expenditures across European countries (Cantillon, 2009; Esping-Andersen \& Myles, 2009; Mehmood \& Sadiq, 2010; Caminada $\&$ Goudswaard, 2010; Caminada et al., 2011). It means that the country's atrisk-of-poverty rate tends to erode with increasing social spending. Despite this strong negative correlation between poverty and social expenditures, some countries manage to reduce poverty quite significantly even with relatively low social expenditure (in the context of other Member States). Looking at Eurostat data, we can see large differences prevailing among EU countries in social protection expenditure as a percentage of GDP. In 2016, the highest levels of social protection expenditure as a percentage of GDP were in France (34.3\%), Finland (31.8\%), and Denmark (31.6\%); countries with the lowest levels included Romania (14.6\%), Latvia (15.2\%), Lithuania (15.4\%), and Ireland $(15.8 \%)$. However, Ireland was among the countries where poverty rate after social transfers was more than halved. It may be assumed that in order to reduce poverty rates, it is important to consider not only the amount allocated to social spending (as a percentage of GDP), but also the areas the social transfers are channelled to. This issue has been little addressed in scientific literature and brings novelty to studies on poverty reduction. The aim of this article is to analyse how the composition and the extent of social transfers may affect poverty reduction in EU countries.

Social sector expenditures in this article are defined in accordance with the European system of integrated social protection statistics (ESSPROS) classification. According to this classification, social expenditure includes 
social protection transfers which are provided to households and individuals affected by a specific set of social risks. The terms "social transfers", "social expenditure" and "social spending" are used interchangeably in the article. In order to identify the poor, we use the European Commission's income poverty definition according to EU-SILC methodology.

It is important to note that the article is limited to the analysis of the effects of social protection transfers on poverty reduction, although some other strategies can be also chosen to alleviate poverty, such as improving job opportunities, increasing labour force participation, etc.

The research techniques applied in the article include: analysis of literature, comparative analysis, descriptive statistics, correlation analysis, and regression analysis. The analysis is based on Eurostat data.

\section{Social transfers as an instrument for poverty reduction}

Over the last few decades, economic growth has been given particular importance with regard to poverty reduction. Many authors noted that economic growth has been one of the main drivers for reduction of poverty and improvement of the quality of life (Schmidt, 2005; Foster \& Székely, 2001; Dagdeviren et al., 2002; Troitiño, 2013). According to Kraay (2006), growth in average incomes accounts for some $70 \%$ to $95 \%$ of poverty reduction. Other studies find that around two-thirds of the drop in poverty rates is the result of economic growth (Pérez de la Fuente, 2016).

Despite the importance of economic growth, a number of studies emphasise that economic growth alone is not sufficient to reduce relative poverty unless accompanied by government efforts (Narayan et al., 2013; Moges, 2013). Findings of the studies at issue are in line with the ideas of the Social Democratic Theory of Poverty, which highlights the importance of welfare states in the fight against poverty and exclusion and in increasing the opportunities for the poor to participate in the labour market and social life. The Social Democratic Approach strongly favours a welfare state and suggests that welfare is vital in order to regulate the negative effects of a capitalist society. According to supporters of this approach, states must ensure that all citizens are guaranteed a minimum income, which in turn would further serve poverty alleviation (Odekon, 2015).

Today, social transfers are being increasingly recognised as an instrument that has proven to be effective in reducing poverty in many countries. Caminada et 
al. (2011) have examined the relationship between poverty and social transfer spending, as well as a number of macroeconomic and demographic variables. They found that such indicators as the unemployment rate, the elderly population and GDP per capita all affect the poverty rate. However, they suggest that the most important and effective tool for fighting poverty is social spending.

Countries may provide universal or means-tested social benefits depending on the welfare model. Universal social protection means that the entire population of a country (regardless of economic or socio-demographic characteristics) is granted a guaranteed minimum income or consumption level and access to basic services. On the other hand, targeted social support refers to the process when public resources are focused on a target group of population, identified on the basis of certain criteria, such as income or vulnerability (Hujo \& Gaia, 2011).

A review of studies on the relationship between social spending and poverty reduction in EU and non-EU countries is provided in this article below.

\section{Relationship between social transfers and poverty reduction}

A number of studies conducted over the past two decades have found that there is a strong negative correlation between poverty and social transfers. It means that countries with a higher level of social expenditure are likely to have lower poverty rates (Caminada \& Goudswaard, 2009; Forster \& d'Ercole, 2005; Anderson et al., 2018; Kim, 2000; Leventi et al., 2018). Public spending affects poverty reduction in several ways: it can raise the overall growth performance of the economy, and it can increase the chance of the poor to contribute to the growth process (mainly by strengthening human capabilities and reducing transaction costs). Government social spending may also have positive impacts on growth and poverty reduction by improved provision of social services, public goods spending, and better infrastructure access (Wilhelm \& Fiestas, 2005).

However, despite the strong negative correlation between poverty and social expenditures, it should be noted that the impact of government spending on poverty may vary according to the sector of spending, how well it is targeted, and the way in which it is financed. The effect may also differ according to the time period of analysis, since some types of spending have direct, immediate impacts on poverty (e.g., transfers and subsidies), while others only have more indirect, medium-term effects (e.g., health, education, and infrastructure 
spending) (Anderson et al., 2018). Caminada and Goudswaard (2009) found that the effect of public spending on poverty is less strong in EU countries compared to non-EU-15 countries. Celikay and Gumus (2017) found that in the short run there is a negative relationship between social expenditure and poverty, but in the long run there exists a positive correlation between social expenditure and poverty.

In Table 1, we provide the review of the studies that focus on the relationship between social spending and poverty reduction.

Table 1. Studies focusing on the relationship between social spending and poverty reduction

\begin{tabular}{|c|c|c|}
\hline Authors & Aim/Methodology & Main results \\
\hline $\begin{array}{l}\text { Leventi, C.; } \\
\text { Sutherland, H. } \\
\text { \& Valentinova } \\
\text { Tasseva, I. (2018) }\end{array}$ & $\begin{array}{l}\text { The authors examined how } \\
\text { income poverty is affected by } \\
\text { changes to the scale of tax- } \\
\text { benefit policies and which are } \\
\text { the most cost-effective policies } \\
\text { in reducing poverty or limiting } \\
\text { its increase in seven diverse } \\
\text { EU countries. }\end{array}$ & $\begin{array}{l}\text { The researchers found that } \\
\text { the most preferred options } \\
\text { in terms of poverty reduction } \\
\text { cost-effectiveness were child } \\
\text { benefits and social assistance. }\end{array}$ \\
\hline $\begin{array}{l}\text { Anderson, E.; } \\
\text { M. d'Orey, A. J.; } \\
\text { Duvendack, M. } \\
\text { \& Espositoa, L. } \\
\text { (2018) }\end{array}$ & $\begin{array}{l}\text { The authors carried out a } \\
\text { meta-regression analysis } \\
\text { of the relationship between } \\
\text { government spending and } \\
\text { income poverty, with a focus } \\
\text { on low- and middle-income } \\
\text { countries. }\end{array}$ & $\begin{array}{l}\text { The authors found no } \\
\text { clear evidence that higher } \\
\text { government spending had } \\
\text { played a significant role in } \\
\text { reducing income poverty in low- } \\
\text { and middle-income countries. } \\
\text { The authors concluded that } \\
\text { fiscal policy plays a much } \\
\text { more limited redistributive } \\
\text { role in developing countries, } \\
\text { in comparison with OECD } \\
\text { countries. }\end{array}$ \\
\hline $\begin{array}{l}\text { Celikay, F. \& } \\
\text { Gumus, E. (2017) }\end{array}$ & $\begin{array}{l}\text { The authors analysed the } \\
\text { relationship between social } \\
\text { expenditure and poverty in } \\
\text { Turkey. The authors used panel } \\
\text { error correction models and } \\
\text { employed Turkish statistical } \\
\text { territorial units data ( } 26 \\
\text { regions) covering the period } \\
2004-2011 \text { in the analysis. }\end{array}$ & $\begin{array}{l}\text { The authors have found that } \\
\text { in the short run, there is a } \\
\text { negative relationship between } \\
\text { social expenditure and poverty. } \\
\text { The authors obtained a } \\
\text { negative relationship between } \\
\text { education expenditure and } \\
\text { poverty, both in the short run } \\
\text { and in the long run. }\end{array}$ \\
\hline
\end{tabular}




\begin{tabular}{|c|c|c|}
\hline Authors & Aim/Methodology & Main results \\
\hline $\begin{array}{l}\text { Lustig, N.; } \\
\text { Pessino, C. \& } \\
\text { Scott, J. (2016) }\end{array}$ & $\begin{array}{l}\text { The authors analysed the } \\
\text { impact of taxes and social } \\
\text { spending on inequality and } \\
\text { poverty in Latin American } \\
\text { countries. The method of } \\
\text { standard fiscal incidence } \\
\text { analysis using a comparable } \\
\text { methodology was implemented. }\end{array}$ & $\begin{array}{l}\text { The authors found that direct } \\
\text { taxes and cash transfers } \\
\text { reduce inequality and poverty } \\
\text { by nontrivial amounts in } \\
\text { Argentina, Brazil, and Uruguay, } \\
\text { less so in Mexico and relatively } \\
\text { little in Bolivia and Peru. The } \\
\text { authors also conclude that in- } \\
\text { kind transfers in education and } \\
\text { health reduce inequality in all } \\
\text { countries by considerably more } \\
\text { than cash transfers. }\end{array}$ \\
\hline $\begin{array}{l}\text { Notten, G. \& } \\
\text { Guio, A. C. (2016) }\end{array}$ & $\begin{array}{l}\text { The authors aimed to } \\
\text { determine the degree to which } \\
\text { social transfers reduce material } \\
\text { deprivation using a simulation } \\
\text { method. The method was } \\
\text { applied to pre-recession and } \\
\text { post-austerity EU-SILC data for } \\
\text { Germany, Greece, Poland and } \\
\text { the United Kingdom. }\end{array}$ & $\begin{array}{l}\text { The authors found that a } 1 \% \\
\text { income transfer reduces the } \\
\text { number of material deprivations } \\
\text { by an order of } 0.51 \% \text { in } \\
\text { Germany, } 0.43 \% \text { in Greece, } \\
0.40 \% \text { in Poland, and } 0.33 \% \text { in } \\
\text { the United Kingdom. }\end{array}$ \\
\hline $\begin{array}{l}\text { Caminada, K. \& } \\
\text { Goudswaard, K. } \\
(2010)\end{array}$ & $\begin{array}{l}\text { The authors performed a } \\
\text { cross-national analysis of } \\
\text { the relationship between } \\
\text { (public and private) social } \\
\text { expenditures and poverty } \\
\text { reduction through transfers and } \\
\text { taxes. }\end{array}$ & $\begin{array}{l}\text { The authors found that each } \\
\text { percentage point of social } \\
\text { expenditure alleviates poverty } \\
\text { in both EU- } 15 \text { and non-EU-15 } \\
\text { on average by } 0.7 \text { percentage } \\
\text { points. }\end{array}$ \\
\hline $\begin{array}{l}\text { Caminada, K. \& } \\
\text { Goudswaard, K. } \\
\text { (2009) }\end{array}$ & $\begin{array}{l}\text { The authors analysed the } \\
\text { effectiveness of social transfers } \\
\text { in alleviating poverty by } \\
\text { focusing on EU- } 15 \text { countries } \\
\text { and some OECD countries. }\end{array}$ & $\begin{array}{l}\text { The authors found that social } \\
\text { spending is an important } \\
\text { determinant of a country's } \\
\text { poverty outcome, especially } \\
\text { among the elderly, when } \\
\text { pensions are considered as } \\
\text { transfers. }\end{array}$ \\
\hline $\begin{array}{l}\text { Wilhelm, V. \& } \\
\text { Fiestas, I. (2005) }\end{array}$ & $\begin{array}{l}\text { The study explored how the } \\
\text { composition of public spending } \\
\text { and the manner in which the } \\
\text { public resources are spent may } \\
\text { have affected the ability of poor } \\
\text { people to connect to growth in } \\
\text { the } 1990 \text { s. }\end{array}$ & $\begin{array}{l}\text { The study found that in a period } \\
\text { of declining overall spending } \\
\text { in per capita terms, spending } \\
\text { increased most significantly in } \\
\text { non-productive sectors (except } \\
\text { for education). }\end{array}$ \\
\hline
\end{tabular}

Source: Composed by the authors 
Despite the multiplicity of the studies, there appears to be little research on what particular types of social spending contribute most to the reduction of poverty in EU countries. The present study builds on the existing literature to statistically test how the composition and the extent of social spending affect poverty reduction in EU countries.

\section{Research methodology}

In this article, social expenditures are defined as social protection expenditures which include eight main types of social risks according to the ESSPROS classification: disability, sickness/health care, old age, survivors, family/ children, unemployment, housing, social exclusion. According to Eurostat methodology, expenditures on social protection include social benefits, which consist of transfers in cash or in kind, administration costs, and other expenditure (payment of property income and other).

Statistics on income and living conditions (EU-SILC) methodology is used to identify the poor. An individual is considered to be at risk of poverty when he or she lives in a household whose total equivalised income is below the at-risk-ofpoverty threshold, defined as $60 \%$ of the national median equivalised income.

In order to assess the linkages between social transfers and variation of poverty rates, Eurostat data for the years 2008 to 2016 are used in the analysis $(\mathrm{N}=252)$.

There are three main indicators used to measure changes in the at-risk-ofpoverty rate before and after social transfers:

1) The difference between the at-risk-of-poverty rate before and after social transfers (in percentage points) which is indicative of an absolute antipoverty effect.

2) A percentage change in the poverty rate after social transfers compared to the at-risk-of-poverty rate before social transfers, which is indicative of a relative antipoverty effect.

3) Public policy effectiveness on poverty alleviation is calculated based on the methodology introduced by Caminada and Goudswaard (2010). Following this methodology, absolute antipoverty effects are first calculated for each country. Then absolute antipoverty effects are divided by social spending ratios (as a percentage of GDP) to see which country targets poverty best per one point of GDP spent on social expenditure (Caminada \& Goudswaard, 2010, p. 6). 
It should be noted that pensions are excluded from measuring antipoverty effects (absolute and relative) in this article. Account is taken of the EC's position whereby pensions "are considered primary income since their role is not only to redistribute resources across income groups but also, and primarily, over the life-cycle of individuals and/or across generations" (Joint Report 6694/07, p. 25).

It is important to mention that the depth of the analysis in the article was constraint by the limited availability of comparable data on poverty rates and public spending. It was important to use the indicators that were calculated using a similar (in our case, Eurostat) methodology. For this reason, only 28 EU countries were included in the analysis. Furthermore, the literature analysis has showed that cross-country regressions and computable general equilibrium (CGE) models are the most common tools used to establish the links between expenditure components and poverty reduction. However, CGE models are technically demanding and data-intensive as well as structural parameters are difficult to estimate (Wilhelm \& Fiestas, 2005). For this reason, in order to assess the relationship between relative antipoverty effects with different types of social protection expenditure, the Spearman correlation was calculated and a linear regression analysis was carried out. The regression analysis used the indicator of relative antipoverty effect, as it allows a more accurate gauging of changes in at-risk-of-poverty rates before and after social transfers.

\section{Impact of social transfers on poverty in EU countries}

Absolute antipoverty effects are shown in Figure 1. As we can see, social transfers reduce the percentage of people at risk of poverty in all the countries, however to a very different extent. The largest reduction is seen in Ireland and Scandinavian countries (Finland, Sweden and Denmark), while Italy, Romania and Greece demonstrate the lowest reduction.

As shown in Figure 2, results are similar in calculating relative antipoverty effects. The highest percentage reduction is recorded in Finland (56.9\%), Ireland $(52.6 \%)$ and Denmark (51\%). The share of people at risk of poverty after social transfers decreased by more than half in those countries, while Greece exhibited only a $15.8 \%$ reduction. 


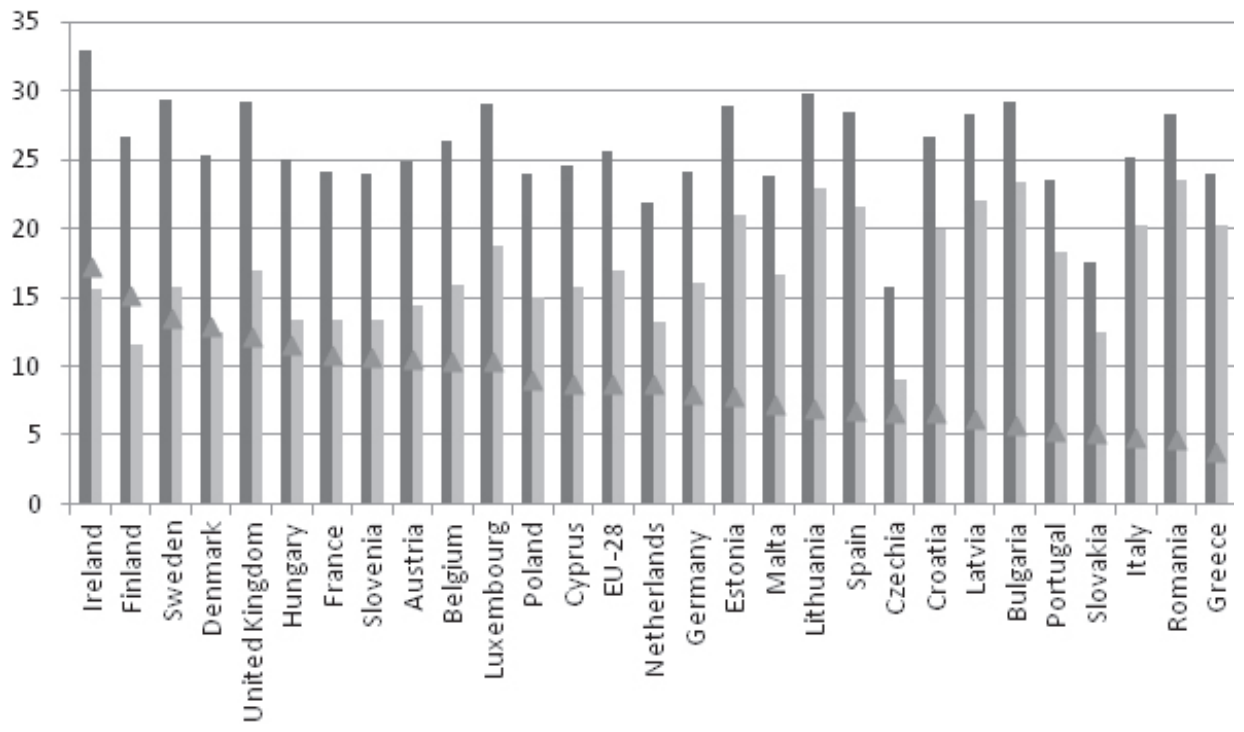

at risk of poverty rate before social transfers at risk of poverty rate after social transfers $\triangle$ Absolute antipoverty effect

Figure 1. Absolute antipoverty effect in EU countries in 2017 (pensions excluded from social transfers), $\%$

However, the analysis above does not say anything about the amount of expenditure on social protection in different EU countries. It could be that countries exhibiting the greatest poverty alleviation also have the highest expenditure on social protection. In order to determine the countries which are the most effective in alleviating poverty, it is appropriate to measure public policy effectiveness on poverty alleviation across Member States (Table 2).

When we rank countries according to their effectiveness in combating poverty (Table 2, column 7), Ireland appears to stand out in its effectiveness. In this country, each percentage point of social expenditure reduces poverty by 1.15 percentage points. Although Ireland's spending on social protection as a percentage of GDP is one of the lowest in the EU, its absolute antipoverty effect of social transfers is the highest among the EU-28 countries, meaning that social transfers in this country reach the most vulnerable population groups. According to Heady et al. (2001), Ireland's high effectiveness in alleviating poverty has been determined by a combination of the high proportion of means-testing in Ireland's social transfers.

Other countries demonstrating sufficiently high effectiveness in alleviating poverty include Hungary (0.59), Finland (0.48), Luxembourg (0.48), the United 


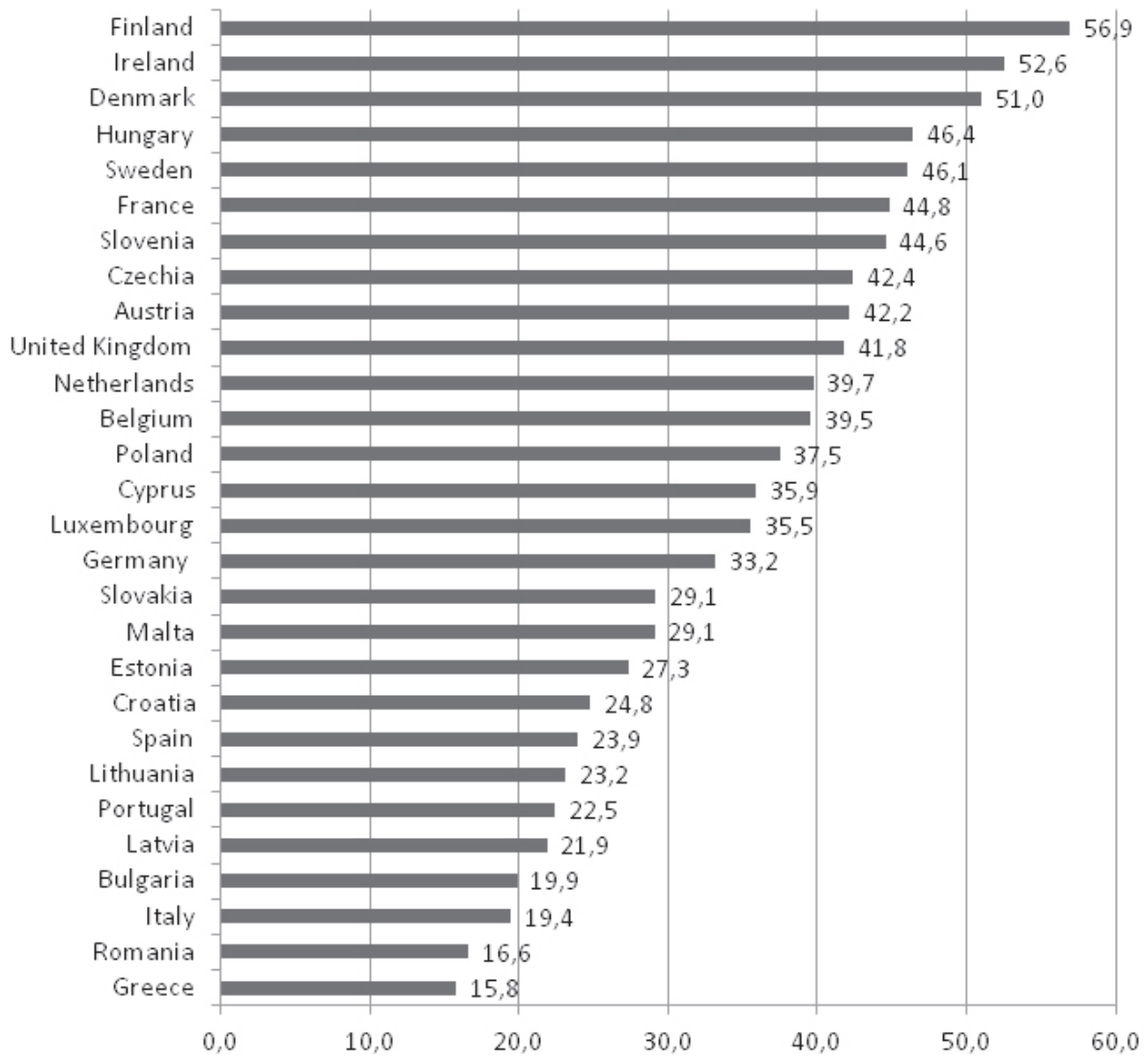

Figure 2. Relative antipoverty effect in 2017 (pensions excluded from social transfers), \%

Kingdom (0.47), and Cyprus (0.47). The lowest effectiveness is observed in Greece and Italy ( 0.15 and 0.19 percentage points, respectively), although, as seen in Table 2 (column 6), the latter countries spend considerably more on social protection (as a percentage of GDP) compared to Hungary or Ireland.

It is important to mention that within the group of the EU-28 countries, a statistically significant relationship has been found between levels of social expenditure and antipoverty effect (both absolute and relative) of social expenditure. This supports the findings of the abovementioned empirical studies showing that the higher the social expenditures, the more noticeable the antipoverty effect (Table 3 ). 
Table 2. Targeting effect of social expenditure on poverty reduction in EU-28 in 2016

\begin{tabular}{|c|c|c|c|c|c|c|c|c|}
\hline & 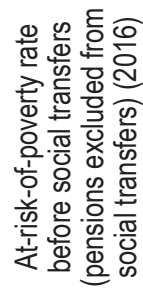 & 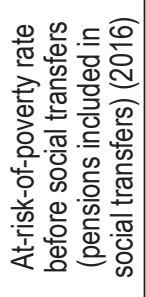 & 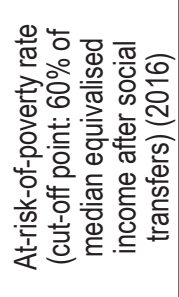 & 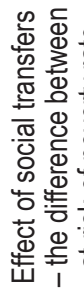 & 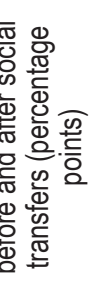 & 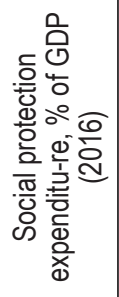 & 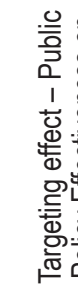 & 豙 \\
\hline & 1 & 2 & 3 & 4 & 5 & 6 & 7 & 8 \\
\hline & & & & $1-3$ & $2-3$ & & $4 / 6$ & $5 / 6$ \\
\hline Belgium & 26.3 & 44.2 & 15.5 & 10.8 & 28.7 & 29.8 & 0.36 & 0.96 \\
\hline Bulgaria & 27.9 & 45.6 & 22.9 & 5 & 22.7 & 17.5 & 0.29 & 1.30 \\
\hline Czechia & 16.3 & 36.5 & 9.7 & 6.6 & 26.8 & 18.9 & 0.35 & 1.42 \\
\hline Denmark & 24.9 & 40.3 & 11.9 & 13 & 28.4 & 31.6 & 0.41 & 0.90 \\
\hline Germany & 25.3 & 43.5 & 16.5 & 8.8 & 27 & 29.4 & 0.30 & 0.92 \\
\hline Estonia & 28.9 & 39.6 & 21.7 & 7.2 & 17.9 & 16.6 & 0.43 & 1.08 \\
\hline Ireland & 34.7 & 44.6 & 16.6 & 18.1 & 28 & 15.8 & 1.15 & 1.77 \\
\hline Greece & 25.1 & 52.9 & 21.2 & 3.9 & 31.7 & 26.6 & 0.15 & 1.19 \\
\hline Spain & 29.5 & 46.8 & 22.3 & 7.2 & 24.5 & 24.3 & 0.30 & 1.01 \\
\hline France & 23.5 & 45.1 & 13.6 & 9.9 & 31.5 & 34.3 & 0.29 & 0.92 \\
\hline Croatia & 27.3 & 44.8 & 19.5 & 7.8 & 25.3 & 21.3 & 0.37 & 1.19 \\
\hline Italy & 26.2 & 46.5 & 20.6 & 5.6 & 25.9 & 29.7 & 0.19 & 0.87 \\
\hline Cyprus & 25.0 & 38.3 & 16.1 & 8.9 & 22.2 & 19.1 & 0.47 & 1.16 \\
\hline Latvia & 27.8 & 40.2 & 21.8 & 6 & 18.4 & 15.2 & 0.39 & 1.21 \\
\hline Lithuania & 27.9 & 42.1 & 21.9 & 6 & 20.2 & 15.4 & 0.39 & 1.31 \\
\hline Luxembourg & 27.1 & 44.4 & 16.5 & 10.6 & 27.9 & 22.0 & 0.48 & 1.27 \\
\hline Hungary & 25.8 & 47.7 & 14.5 & 11.3 & 33.2 & 19.2 & 0.59 & 1.73 \\
\hline Malta & 23.8 & 37.9 & 16.5 & 7.3 & 21.4 & 16.7 & 0.44 & 1.28 \\
\hline Netherlands & 22.0 & 38.5 & 12.7 & 9.3 & 25.8 & 29.5 & 0.32 & 0.87 \\
\hline Austria & 26.3 & 44.8 & 14.1 & 12.2 & 30.7 & 30.3 & 0.40 & 1.01 \\
\hline Poland & 22.7 & 43.5 & 17.3 & 5.4 & 26.2 & 20.3 & 0.27 & 1.29 \\
\hline Portugal & 25.0 & 46.1 & 19.0 & 6 & 27.1 & 25.2 & 0.24 & 1.08 \\
\hline Romania & 29.4 & 49.5 & 25.3 & 4.1 & 24.2 & 14.6 & 0.28 & 1.66 \\
\hline Slovenia & 24.3 & 41.2 & 13.9 & 10.4 & 27.3 & 23.3 & 0.45 & 1.17 \\
\hline Slovakia & 18.4 & 37.9 & 12.7 & 5.7 & 25.2 & 18.4 & 0.31 & 1.37 \\
\hline Finland & 27.0 & 43.7 & 11.6 & 15.4 & 32.1 & 31.8 & 0.48 & 1.01 \\
\hline Sweden & 29.8 & 45.0 & 16.2 & 13.6 & 28.8 & 29.6 & 0.46 & 0.97 \\
\hline $\begin{array}{c}\text { United } \\
\text { Kingdom }\end{array}$ & 28.1 & 42.7 & 15.9 & 12.2 & 26.8 & 26.2 & 0.47 & 1.02 \\
\hline EU-28 & 25.9 & 44.5 & 17.3 & 8.6 & 27.2 & 28.1 & 0.30 & 0.96 \\
\hline
\end{tabular}

Calculations based on Caminada and Goudswaard's (2010) methodology.

Data source: Eurostat ([spr_exp_sum], [ilc_li02], [ilc_li09b], [ilc_li10b]) 
Table 3. Correlation between levels of social expenditure and antipoverty effects of social expenditure (Spearman's rho)

\begin{tabular}{|c|c|c|}
\hline & $\begin{array}{c}\text { Absolute antipoverty } \\
\text { effect }\end{array}$ & $\begin{array}{c}\text { Relative antipoverty } \\
\text { effect }\end{array}$ \\
\hline $\begin{array}{c}\text { Social protection } \\
\text { expenditure, percentage } \\
\text { of GDP } \\
(2008-2016, N=249)\end{array}$ & $0.493^{* *}$ & $0.486^{* *}$ \\
\hline $\begin{array}{c}\text { Social protection benefits, } \\
\text { percentage of GDP } \\
(2008-2016, N=249)\end{array}$ & $0.494^{* *}$ & $0.486^{* *}$ \\
\hline $\begin{array}{c}\text { Social protection benefits, } \\
\text { PPS per inhabitant } \\
(2008-2016, N=249)\end{array}$ & $0.586^{* *}$ & $0.592^{* *}$ \\
\hline
\end{tabular}

${ }^{* *}$ Correlation is significant at the 0.01 level (2-tailed).

We carried out correlation and regression analyses to identify the particular types of social expenditure that are the most effective in alleviating poverty in EU countries. Table 4 illustrates the correlation between the absolute and relative effect of social transfers on poverty reduction and different types of social transfers. As shown, the absolute antipoverty effect appears to have the strongest correlation with family/children and housing expenditure. The relative antipoverty effect is found to have the strongest correlation with family/children and social exclusion expenditure.

The Eurostat's database also contains data for composite variables 'Sickness, health care and disability expenditure' and 'Housing and social exclusion expenditure'. It is interesting to note that the linkages between the composite variables and absolute/relative antipoverty effects demonstrate considerably higher correlation coefficients compared to the correlation coefficients between the original variables (Table 4). However, since our aim was to identify which type of social expenditures has the strongest influence on the relative antipoverty effect in the regression analysis we will use separate variables.

As it was mentioned, in order to identify the influence of social expenditures on the relative antipoverty effect, the linear regression analysis was used. Before the linear regression analysis, the linearity patterns between dependent and all independent variables were checked using scatter plots (Fig. 3). 
Table 4. Correlation between the effect of social transfers on poverty reduction and different types of social transfers (Spearman's rho)

\begin{tabular}{|c|c|c|c|c|c|c|c|c|}
\hline & \multicolumn{8}{|c|}{ Percentage of GDP, 2013-2016 } \\
\hline & $\begin{array}{l}\text { Sick- } \\
\text { ness/ } \\
\text { Health } \\
\text { care } \\
\text { expendi- } \\
\text { ture }\end{array}$ & $\begin{array}{l}\text { Disability } \\
\text { expendi- } \\
\text { ture }\end{array}$ & $\begin{array}{l}\text { Old age } \\
\text { expendi- } \\
\text { ture }\end{array}$ & $\begin{array}{l}\text { Survi- } \\
\text { vors } \\
\text { expendi- } \\
\text { ture }\end{array}$ & $\begin{array}{l}\text { Family/ } \\
\text { Children } \\
\text { expendi- } \\
\text { ture }\end{array}$ & $\begin{array}{l}\text { Un- } \\
\text { employ- } \\
\text { ment } \\
\text { expendi- } \\
\text { ture }\end{array}$ & $\begin{array}{l}\text { Housing } \\
\text { expendi- } \\
\text { ture }\end{array}$ & $\begin{array}{l}\text { Social } \\
\text { ex- } \\
\text { clusion } \\
\text { expendi- } \\
\text { ture }\end{array}$ \\
\hline \multirow{2}{*}{$\begin{array}{c}\text { Absolute } \\
\text { antipoverty } \\
\text { effect } \\
(2008-2016 \text {, } \\
\left.N=249^{*}\right)\end{array}$} & $0.519^{* *}$ & $0.488^{* *}$ & \multirow[t]{2}{*}{0.120} & \multirow[t]{2}{*}{$-0.130^{*}$} & \multirow[t]{2}{*}{$0.689^{* *+}$} & \multirow[t]{2}{*}{$0.404^{* *}$} & $0.550^{* *}$ & $0.526^{* *}$ \\
\hline & \multicolumn{2}{|c|}{$0.590^{* *}$} & & & & & 0.7 & $47^{* *}$ \\
\hline Relative & $0.524^{* *}$ & $0.430^{* * *}$ & \multirow[t]{2}{*}{0.121} & \multirow[t]{2}{*}{$-0.155^{*}$} & \multirow[t]{2}{*}{$0.619^{*}$} & \multirow[t]{2}{*}{$0.389^{* *}$} & $0.496^{* *}$ & $0.555^{* *}$ \\
\hline $\begin{array}{c}\text { antipoverty } \\
\text { effect } \\
(2008-2016, \\
\left.N=249^{*}\right)\end{array}$ & \multicolumn{2}{|c|}{$0.588^{* *}$} & & & & & \multicolumn{2}{|c|}{$0.753^{* *}$} \\
\hline
\end{tabular}

* Exceptions: Housing expenditure $N=166$, Social exclusion expenditure $N=247$.

${ }^{* *}$ Correlation is significant at the 0.01 level (2-tailed).

The variables and characteristics of the initial and final models are presented in Table 5. The final model includes three independent variables - social exclusion as a percentage of GDP, family/children expenditure as a percentage of GDP, and sickness/healthcare expenditures as a percentage of GDP - that are statistically significant at the 0.01 level. The final model's equation is:

\section{Relative antipoverty effect of social transfers $=7.360+9.419 *$ social exclusion expenditure as \% of GDP $+6.623 *$ family/children expenditure as \% of GDP + 1.824*sickness and healthcare expenditure as \% of $G D P+e$}

The final model's equation shows that social exclusion expenditure exhibits the highest effect on poverty reduction in EU countries. Any $1 \%$ increase in social exclusion expenditure as a percentage of GDP leads to a $9.4 \%$ increase in relative antipoverty effect of social transfers when all other variables are held constant in the model. Effects of family/children expenditure and sickness and healthcare expenditure on poverty reduction are considerably lower but nonetheless statistically significant. According to Eurostat methodology, social exclusion expenditures include targeted spending on social exclusion which is not covered by other types of expenditure. As we can see, this type of social 
Figure 3. Correlation between relative antipoverty effect and different types of social expenditure
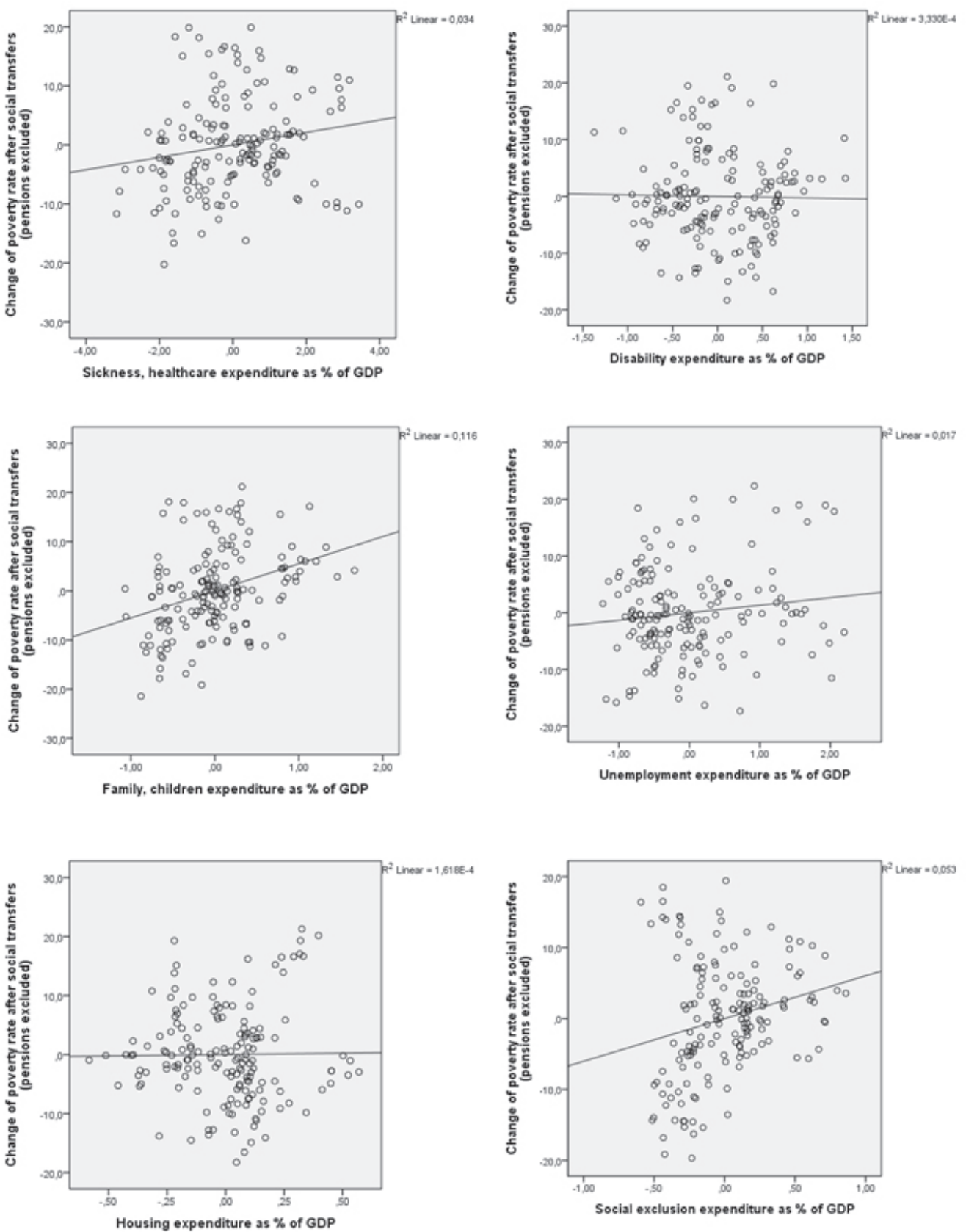
expenditure contributes most to poverty reduction. Since families with children tend to be at risk of poverty more often compared to families without children (according to Eurostat, in 2017, at-risk-of-poverty rate among families with three or more dependent children was $26.9 \%$, while the same indicator among families without dependent children constituted only $11.1 \%$ in EU-28) family/ children expenditure also has a major impact on poverty reduction.

Table 5. Relative antipoverty effect variables (characteristics of linear regression)

\begin{tabular}{|l|c|c|}
\hline & Initial Model & Final Model \\
\hline $\begin{array}{l}\text { Dependent variable: } \\
\text { Relative antipoverty effect }\end{array}$ & & \\
\hline Regressors (independent variables) & & \\
\hline Social exclusion expenditure & $6.027^{*}$ & 9.419 \\
as a percentage of GDP & $0.003^{* *}$ & 0.000 \\
\hline Family, children expenditure & 5.515 & 6.623 \\
as a percentage of GDP & 0.000 & 0.000 \\
\hline Sickness, healthcare expenditure & 1.054 & 1.824 \\
as a percentage of GDP & 0.021 & 0.000 \\
\hline Unemployment expenditure as a percentage & 1.325 & \\
of GDP & 0.101 & \\
\hline Housing expenditure as a percentage & 0.465 & \\
of GDP & 0.874 & \\
\hline Disability expenditure as a percentage & -0.268 & \\
of GDP & 0.819 & \\
\hline Constant & 17.106 & 7.360 \\
\hline R square & 0.442 & .560 \\
\hline Adjusted R square & 0.421 & .554 \\
\hline N & 164 & 247 \\
\hline$*$ Unstandardized Coefficients B* & & \\
\hline
\end{tabular}

${ }^{*}$ Unstandardized Coefficients $B,{ }^{* *} p$ value.

The research findings unambiguously reveal the interrelationship between social expenditure and poverty. Actually all types of expenditure on social protection (except old age expenditure) correlate with relative antipoverty effects (survivors expenditure correlation is extremely weak), but social exclusion expenditure, family/children expenditure and sickness/healthcare expenditure have significant effect on poverty reduction.

As the study examined the time period from 2008 to 2016, covering quite different periods of economic cycle (economic crisis and economic upturn), a 
further regression analysis was conducted for the periods 2008-2012 (economic downturn) and 2013-2016 (economic recovery period) to check whether the efficiency of social spending varies depending on the phase of the economic cycle. It should be noted that the regression models obtained did not differ substantially and showed that the relative antipoverty effect is influenced by the same factors-social exclusion expenditure, family/children and sickness/ healthcare expenditure.

\section{Conclusions}

The analysis has shown that social transfers are an effective tool for poverty reduction in EU countries. Social transfers reduce the percentage of people at risk of poverty in all the countries, however to a very different extent. If we analyse absolute and relative antipoverty effects, we may see that Ireland and Scandinavian countries (Finland, Sweden and Denmark) demonstrate the largest reduction, while the lowest reduction is seen in Italy, Romania and Greece.

Similar results have been obtained from calculations of the indicator of public policy effectiveness on poverty alleviation across EU countries, showing which country targets poverty best per one percentage point of GDP spent on social expenditure. Basing the calculations on this indicator, the countries found to be most effective in alleviating poverty are Ireland (in this country, each percentage point of social expenditure reduces poverty by 1.15 percentage points), Hungary (0.59), Finland (0.48), and the United Kingdom (0.47). The indicator of public policy effectiveness on poverty alleviation is the lowest for Greece, Italy and Portugal.

The research has confirmed the findings from previous studies that there exists a statistically significant relationship between levels of social expenditure and antipoverty effects of social expenditure. Countries with higher social expenditure exhibit higher antipoverty effects (both absolute and relative). A strong correlation can be seen between social protection benefits (PPS per inhabitant) and antipoverty effects, showing that increasing social protection benefits are also increasing the difference between at-risk-of-poverty rates before and after social transfers.

Based on the regression analysis, social exclusion expenditure has been found to be the most important predictor of the relative antipoverty effect of social transfers. Even a small increase in the social exclusion expenditure rather 
significantly amplifies the relative antipoverty effect of social transfers. Effects of family/children expenditure and sickness/healthcare expenditure on poverty reduction are considerably lower but nonetheless statistically significant. The analysis yielded the same results for different phases of economic cycleeconomic downturn (2008-2012) and economic recovery (2013-2016).

It should be noted that this antipoverty effect analysis is limited to the effects of different types of social protection expenditures on changes in poverty rates after social transfers and excludes other variables likely to have effects on poverty rates, for example GDP growth, employment, the share of older people in populations, etc. Inclusion of more variables in the analysis is likely to make some adjustments in the findings of the regression analysis. Despite the study limitations, the regression analysis allowed the identification of the most important types of expenditure on social protection having effects on poverty variations.

The analysis has also set a framework for further research. Due to the limited scope of the paper it was not possible to analyse how other variables (e.g., duration of the spending in the specific type of social expenditure) may impact the poverty reduction. Further research could also include the analysis of social spending and anti-poverty effects in a broader context in different EU countries in order to identify why some countries are more effective in reducing poverty than others.

Rasa Miežienè is a senior researcher at the Lithuanian Social Research Centre, Labour Market Research Institute. Her research interests include labour market policy, working conditions, living standards, and poverty measurement. Since 2006, she has been working as a national correspondent for the European Foundation for the Improvement of Living and Working Conditions.

Sandra Krutuliene is a doctor of social sciences (sociology), currently working as researcher at the Lithuanian Social Research Centre, Labour Market Research Institute. Her research interests include social welfare and employment policy, labour market, working conditions, the situation of vulnerable groups under different types of welfare states, and quality of life research. 


\section{References}

Anderson, E.; M. d'Orey, A. J.; Duvendack, M. \& Espositoa, L. (2018), 'Does government spending affect income poverty? A meta-regression analysis,' World Development, vol. 103 (March), pp. 60-71. https://doi.org/10.1016/j.worlddev.2017.10.006

Caminada, K. \& Goudswaard, K. (2009), 'Social Expenditure and Poverty Reduction in the EU-15 and other OECD Countries,' Department of Economics Research Memorandum 2009.02, Leiden University. https://doi.org/10.2139/ssrn.1553803

Caminada, K. \& Goudswaard, K. P. (2010), 'How well is social expenditure targeted to the poor?' in P. Saunders \& R. Sainsbury (eds.) Social Security, Poverty and Social Exclusion in Rich and Poorer Countries, International Studies on Social Security, vol. 16, Belgium: Intersentia, pp. 97-112.

Caminada, K.; Goudswaard, K. \& Koster, F. (2011), 'Social income transfers and poverty: A cross-country analysis for OECD countries,' International Journal of Social Welfare, no. 21, pp. 115-126.

https://doi.org/10.1111/j.1468-2397.2011.00815.x

Cantillon, B. (2009), 'Poverty and social security: the paradox of the social investment state in the rich egalitarian EU member states,' Paper presented at FISS Conference, Sigtuna, Sweden, 16-18 June 2009.

Celikay, F. \& Gumus E. (2017), 'The effect of social spending on reducing poverty,' International Journal of Social Economics, vol. 44, no. 5, pp. 620-632. https://doi.org/10.1108/IJSE-10-2015-0274

Dagdeviren, H.; van der Hoeven, R. \& Weeks, J. (2002), 'Poverty reduction with growth and redistribution,' Development and Change, vol. 33, no. 3, pp. 383-413. https://doi.org/10.1111/1467-7660.00260

Esping-Andersen, G. \& Myles, J. (2009), 'Economic inequality and the welfare state,' in W. Salverda, B. Nolan \& T. M. Smeeding (eds.) The Oxford Handbook of Economic Inequality, Oxford: Oxford University Press, pp. 639-666.

Eurostat (2018), 'How much do social transfers reduce poverty?' Products Eurostat News, 13 November..

Förster, M. \& d'Ercole, M. M. (2005), Income Distribution and Poverty in OECD Countries in the Second Half of the 1990s, OECD Social, Employment and Migration Working Papers, no. 22, OECD. https://doi.org/10.2139/ssrn.671783

Foster, J. E. \& Székely, M. (2001), 'Is economic growth good for the poor?' Paper presented at WIDER Development Conference on Growth and Poverty, Helsinki, Finland, 25-26 May 2001.

Heady, C.; Mitrakos, T. \& Tsakloglou, P. (2001), The Distributional Impact of Social Transfers in the European Union: Evidence from the ECHP, IZA Discussion Paper, no. 356, Institute for the Study of Labor. 
Joint Report (6694/07) on Social Protection and Social Inclusion 2007, Council of the European Union, Brussels, 23.02.2007.

Katja, H. \& Gaia, E. (2011), 'Social policy and poverty: an introduction,' International Journal of Social Welfare, vol. 3, no. 20, pp. 230-239.

https://doi.org/10.1111/j.1468-2397.2011.00786.x

Kim, H. (2000), 'Anti-poverty effectiveness of taxes and income transfers in welfare states,' International Social Security Review, vol. 53, no. 4, pp. 105-129. https://doi.org/10.1111/1468-246X.00107

Leventi, C.; Sutherland, H. \& Valentinova Tasseva, I. (2018), 'Improving poverty reduction in Europe: What works best where?' Journal of European Social Policy, vol. 29, no. 1, pp. 29-43. https://doi.org/10.1177/0958928718792130

Lustig, N.; Pessino, C. \& Scott, J. (2014), 'The impact of taxes and social spending on inequality and poverty in Argentina, Bolivia, Brazil, Mexico, Peru, and Uruguay: Introduction to the Special Issue,' Public Finance Review, vol. 42, no. 3, pp. 287-303. https://doi.org/10.1177/1091142113506931

Mehmood, R. \& Sadiq, S. (2010), 'The relationship between government expenditure and poverty: A cointegration analysis,' Romanian Journal of Fiscal Policy, vol. 1, no. 1, pp. 29-37.

Moges, A. G. (2013), 'Economic growth, inequality and poverty in developing countries: policy issues and challenges,' International Journal of Economic Policy Studies, vol. 8, no. 1, pp. 41-66. https://doi.org/10.1007/BF03405744

Narayan, A.; Saavedra-Chanduvi, J. \& Tiwari, S. (2013), Shared Prosperity: Links to Growth, Inequality and Inequality of Opportunity, Policy Research Working Group, no. 6649, The World Bank. https://doi.org/10.1596/1813-9450-6649

Notten, G. \& Guio, A. C. (2016), The Impact of Social Transfers on Income Poverty and Material Deprivation, ImPRovE Working Paper, no. 16/17, Antwerp: Herman Deleeck Centre for Social Policy, University of Antwerp.

Odekon, M., ed. (2015), The SAGE Encyclopedia of World Poverty, Los Angeles, CA: SAGE Publications, Inc. https://doi.org/10.4135/9781483345727

Pérez de la Fuente, B. (2016), Economic Growth and Poverty Reduction in a Rapidly Changing World, Economic Brief, no. 19, Brussels: European Commission, Directorate-General for Economic and Financial Affairs.

Schmidt, R. (2005), 'Poverty-reducing growth strategy in poor countries,' Revista Latinoamericana de Desarrollo Económico, vol. 5, no. 1.

Troitiño, D. (2013), 'The current economic crisis of the EU: genesis, analysis and solutions,' Baltic Journal of European Studies, vol. 3, no. 1(13), pp. 6-28. https:// doi.org/10.2478/bjes-2013-0002

Wilhelm, V. \& Fiestas, I. (2005), Exploring the Link between Public Spending and Poverty Reduction: Lessons from the 90s, Washington, DC: World Bank Institute. 